\title{
KONDISI MENTAL MAHASISWA BARU MENJALANI PERKULIAHAN ONLINE PADA MASA PANDEMI
}

\author{
Dini Rianti \\ Program Studi Psikologi Fakultas Kedokteran Universitas Lambung Mangkurat \\ Email : dinirntii@gmail.com
}

\begin{abstract}
Abstrak
Menjalani perkuliahan di tengah pandemi Covid-19 dapat menyebabkan pengaruh terhadap kesehatan mental mahasiswa baru yang masih berada dalam tahap adaptasi selepas menjalani pendidikan dari sekolah menengah menuju perguruan tinggi. Penguasaan teknologi menjadi tuntutan yang harus dipenuhi dalam menjalani pembelajaran online selain itu mahasiswa juga dituntut untuk dapat lebih aktif dan kreatif dalam menjalani perkuliahan secara online namun semua itu tidak lepas dari berbagai masalah dan kendala yang harus dihadapi dalam pelaksanaan pembelajaran serta berpengaruh terhadap kesehatan mental. Tulisan ini bertujuan untuk mengetahui adanya pengaruh yang signifikan antara perkuliahan online dan pengaruhnya terhadap kondisi mental mahasiswa baru serta untuk mengetahui apa saja permasalahan yang dihadapi dalam menjalani perkuliahan online ditengah pandemi.
\end{abstract}

\section{Kata kunci : covid-19, mental mahasiswa baru, perkuliahan online}

\begin{abstract}
Studying in the midst of the Covid-19 pandemic can have an impact on the mental health of new students who are still in the adaptation stage after undergoing education from high school to college. Mastery of technology is a requirement that must be met in undergoing online learning, besides that students are also required to be more active and creative in online lectures, but all of this cannot be separated from the various problems and obstacles that must be faced in the implementation of learning and affect mental health. This paper aims to determine the significant influence between online lectures and their effect on the mental condition of new students and to find out what problems are faced in undergoing online lectures amid the pandemic.
\end{abstract}

Selama ini kita telah berhadapan dengan pandemi Virus Covid-19 atau dikenal dengan Virus Corona yang telah dinyatakan sebagai pandemi global oleh Organisasi Kesehatan Dunia (WHO) pada 11 Maret 2020.
Infeksi pertama virus ini berawal dari kota Wuhan dengan gejala awal flu yang dianggap sebagai flu biasa sehingga tidak ada yang mengira bahwa hal tersebut merupakan awal dari terinfeksinya seseorang terhadap virus 
Covid-19. Dengan banyaknya turis dari mancanegara yang mengunjungi kota Wuhan tanpa sadar bahwa telah terinfeksi Covid-19 maka virus ini kemudian menyebar dengan cepat ke berbagai negara yang ada di dunia. Penyebaran virus ini begitu cepat, karena hanya melalui interaksi dalam kegiatan sehari-hari atau saling bersentuhan dengan orang yang telah terinfeksi virus tersebut kita juga dapat tertular, karena hal inilah para ahli kesehatan dunia menyarankan supaya diterapkannya social distancing guna memutuskan rantai penyebaran Covid-19 yang telah memakan banyak korban. Banyak negara di dunia memberlakukan karantina, lockdown, serta menutup berbagai instansi yang ada di negara mereka seperti perkantoran, perusahaan, pabrik, serta lembaga pendidikan, dan sebagainya termasuk Indonesia juga memberlakukan hal tersebut.

Keadaan berubah drastis semenjak virus melanda negeri ini, berbagai kegiatan yang menimbulkan keramaian menjadi dibatasi, semua orang wajib menggunakan masker, menja jarak dan kemudian di terapkannya Pembatasan Sosial Berskala Besar (PSBB) yang membuat seluruh masyarakat melaksanakan aktivitas seperti belajar, beribadah, bahkan bekerja harus dilakukan dari rumah. Angka kasus masyarakat positif Covid19 semakin meningkat setiap harinya sehingga telah mengakibatkan banyak korban meninggal dunia. Dalam upaya mencegah semakin banyaknya korban yang bertambah akibat Covid-19 pemerintah menerapkan PSBB dan lockdown di beberapa provinsi dengan angka positif Covid-19 terbanyak, dengan keadaan tersebut maka semua hal dilakukan secara online dengan memanfaatkan kemajuan teknologi yang telah ada termasuk kegiatan belajar. Dengan adanya pandemi ini, pemanfaatan dari kemajuan teknologi sangat diperlukan terutama bagi mahasiswa perguruan tinggi yang dituntut untuk semakin aktif dan meningkatkan kreativitasnya dalam memanfaatkan teknologi sebagai media belajar di tengah pandemi sehingga pandemi bukan menjadi penghalang besar dalam kegiatan perkuliahan yang dilaksanakan secara daring yang menyebabkan setiap mahasiswa harus beradaptasi dengan kegiatan pembelajaran menggunakan teknologi yang ada (Aji, R. H. S. 2020).

Perkuliahan secara online menuntut mahasiswa untuk memiliki kemampuan menguasai teknologi sebagai media pembelajaran, mahasiswa juga harus siap menghadapi berbagai kendala dalam melaksanakan perkuliahan secara online seperti masalah jaringan, keadaan server atau perangkat yang digunakan sering bermasalah, kuota internet yang digunakan juga tidak sedikit. Dampak tersebut sangat dirasakan bagi mahasiswa yang berada di daerah dengan keadaan jaringan yang belum memadai untuk melaksanakan perkuliahan online serta tidak sedikit mahasiswa yang sulit mengerti materi yang dipelajari melalui media online karena berbagai kendala. Selain harus fokus beradaptasi dalam masa transisinya mahasiswa baru juga perlu menjaga kesehatan fisik dan mental karena selama ini tidak sedikit mahasiswa yang mengalami stres karena tidak mampu mengikuti perkuliahan online dengan 
baik yang disebabkan berbagai kendala dan merasa tertekan terutama bagi mahasiswa baru yang masih berproses dalam beradaptasi tentunya memiliki tantangan tersendiri dalam menjalani dan menerima materi perkuliahan, cara berpikir mahasiswa baru merupakan salah satu hal yang mempengaruhi kesehatan mentalnya sendiri karena setiap mahasiswa memiliki pemikiran yang berbeda namun hal tersebut sulit disalahkan dalam menghadapi dan menanggapi situasi seperti ini, saat membaca salah satu karya Prof. Dr. Ersis Warmansyah Abbas, M. Pd. yang berjudul "Menulis Membangun Mindset" saya mengagumi pernyataan beliau yang menyatakan bahwa "Setiap orang mempunyai cara masing-masing, proses berpikir seseorang unik" (Abbas, E. W.2020).

Menghadapi perkuliahan sebagai mahasiswa baru apalagi dalam masa pandemi memang tidak mudah, namun mahasiswa baru perlu menumbuhkan pemikiran atau mindset yang positif supaya kesehatan mentalnya tetap terjaga dengan baik. Tujuan penulisan jurnal ini berupaya mengetahui apa saja permasalahan dan kesulitan yang dihadapi mahasiswa baru dalam perkuliahan online serta hubungan pengaruhnya terhadap kesehatan mental sehingga dapat ditemukan solusi supaya mahasiswa baru dapat tetap menjaga kesehatan mentalnya dalam proses pembelajaran daring di tengah pandemi Covid-19.

\section{METODE}

Metode penelitian untuk penulisan jurnal ini menggunakan metode kajian literatur. Kajian literatur digunakan dengan mengambil dari beberapa judul jurnal yaitu 1). "Pengaruh Stres Akademik Terhadap Academic Help Seeking Pada Mahasiswa Psikologi Unlam Dengan Indeks Prestasi Kumulatif Rendah" (Putri, C. P., Mayangsari, M. D., \& Rusli, R. 2020).

2). "Hubungan Antara Kemandirian Belajar Dengan Komitmen Tugas Pada Mahasiswa Program Studi Psikologi" (Amini, M., Mayangsari, M. D., \& Zwagery, R. V. 2020). Penelitian dalam jurnal yang bersangkutan menggunakan penelitian teknik total sampling, dengan pembahasan pokok mengenai kondisi mental bagi kepentingan akademik mahasiswa. Data diambil menggunakan instrument berupa skala stres akademik dan skala sikap serta dibantu dengan perhitungan dari program statistik komputer.

\section{HASIL DAN PEMBAHASAN}

Pandemi Covid-19 mengakibatkan keadaan berubah total dari dulunya dapat melakukan aktivitas dengan bebas hingga pada masa ini semua aktivitas menjadi terbatas. Dalam bidang pendidikan semua kegiatan dilaksanakan secara online dengan memanfaatkan kemajuan teknologi secara khusus mahasiswa harus memiliki kemampuan dalam memanfaatkan teknologi yang digunakan sebagai media pembelajaran. Mahasiswa baru pada semester pertama yang seharusnya merasakan suasana baru di lingkungan kampus impian hanya bisa memandang kampus dari layar laptop, mahasiswa baru yang harusnya sudah merasakan bagaimana suasana belajar di dalam kampus hanya dapat menerima materi 
perkuliahan melalui aplikasi zoom, Gmeet, classroom, dan lainnya. Perguruan tinggi merupakan tempat bagi mahasiswa mengasah keterampilan guna mempersiapkan diri menjadi tenaga kerja yang kompeten dan profesional dalam bidang pekerjaan yang akan ditekuni nantinya (Putri, P. C., Mayangsari, D. M., \& Rusli, R., 2018). Dalam masa pandemi seperti ini sulit bagi mahasiswa terutama mahasiswa baru yang menerima dan mempelajari materi perkuliahan dari jarak jauh untuk memahami materi perkuliahan dan sedikit sulit untuk menggali potensi yang dimiliki karena melaksanakan pembelajaran secara online tidak sepraktis dan semudah yang dibayangkan terlebih bagi mahasiswa yang berada di daerah yang memiliki keterbatas dalam jangkauan jaringan.

Kendala utama dalam pelaksanaan pembelajaran online adalah jaringan internet yang tidak stabil mengakibatkan mahasiswa sulit memahami materi yang diberikan dosen, penggunaan kuota internet yang sangat boros juga menjadi kesulitan bagi mahasiswa, belum lagi karena keadaan jaringan yang tidak stabil terkadang ada keterlambatan dalam mengumpulkan tugas. Kebanyakan mahasiswa baru mengalami stres dalam menghadapi kendala tersebut, ketika keadaan jaringan naik turun terkadang aplikasi yang digunakan sebagai media pembelajaran dapat tertutup sendiri. Menyesuaikan diri dari seorang siswa SMA menjadi mahasiswa dalam keadaan negeri yang dilanda pandemi tentu merupakan transisi yang sulit bagi mahasiswa baru karena adanya perbedaan yang besar, mahasiswa baru butuh waktu dalam beradaptasi dan menyesuaikan diri dengan keadaan yang dihadapi, namun ada mahasiswa yang merasa kesulitan dalam menyesuaikan diri karena biasanya tidak percaya pada dirinya sendiri sehingga membutuhkan bantuan orang lain dalam penyesuaian tersebut (Mayara, B. H., Yuniarrahmah, E., \& Mayangsari, M. D. 2017).

Kesehatan mental sangat penting untuk dijaga terutama bagi mahasiswa baru yang selama ini memiliki ketakutan, penuh dengan rasa khawatir, hingga terbebani dengan kesulitan yang tengah dihadapi dalam menjalani perkuliahan. Mengikuti pembelajaran online sangat membutuhkan konsentrasi yang tinggi, kesehatan mental juga penting untuk dijaga dan diperhatikan karena dalam menjalani pembelajaran secara online mahasiswa memiliki banyak kendala dan masalah yang dapat mengganggu kesehatan fisik sehingga mengakibatkan hingga jatuh sakit, bukan hanya kesehatan fisik saja, kesehatan mental juga penting untuk diperhatikan dan dijaga apalagi di tengahtengah pandemi yang melanda sekarang ini.

Supaya kesehatan mental tetap terjaga, perlu dimulai dari diri sendiri dengan membangun mindset bahwa kita mampu melakukan dan menghadapi tantangan yang akan dihadapi. Membangun pikiran positif seperti yang ditulis pada karya Prof. Dr. Ersis Warmansyah Abbas, M. Pd., dan Ibu Neka Erlyani, M. Psi, Psikolog dalam sebuah karya berjudul "Menulis Di Kala Badai Covid-19" menyatakan bahwa manusia terlahir dalam bingkai yang disebut tabularasa yang dibentuk oleh lingkungan sosialnya dengan pola pemikiran atau mindset untuk menangkap 
informasi yang diterima ke dalam pikiran (Abbas, E. W., \& Erlyani, N. 2020). Menjaga pikiran supaya dapat tetap berpikir positif serta percaya pada kemampuan diri sendiri adalah hal kecil namun dapat menjadi dampak positif yang besar bagi kesehatan mental, ketika kita mampu mengendalikan pikiran kita dan membangun mindset yang positif contohnya seperti saat diberikan tugas meskipun kurang memahami bagaimana cara pengerjaan tugas tersebut perlu ditanamkan pemikiran bahwa tugas tersebut tidak sulit dan dapat diselesaikan dengan baik dan buang jauh-jauh pemikiran bahwa setiap tugas atau materi yang diberikan adalah hal yang sulit untuk dikerjakan dan dipahami. Dengan berpikir positif secara tidak sadar dapat memberikan stimulasi pada diri sendiri sehingga nantinya benar-benar mampu melakukan dan mengerjakan tugas tersebut dengan baik. Kehidupan sebagai mahasiswa memang sangatlah berbeda dengan kehidupan saat menempuh pendidikan di sekolah menengah, mahasiswa yang menjalani pendidikan di perguruan tinggi merupakan suatu tahap tertinggi dalam pendidikan sehingga dituntut supaya mampu belajar dengan mandiri serta mengerjakan tugas dengan mandiri, namun tidak semua mahasiswa baru dapat melakukannya dengan baik karena masih dalam proses adaptasi, apalagi bagi mahasiswa yang sulit untuk beradaptasi tentunya akan terasa sangat sulit secara penuh melibatkan diri dalam mengerjakan tugas dan memiliki rasa tanggung jawab yang penuh terhadap tugas yang dikerjakan (Amini, M., Mayangsari, M. D., \& Zwagery, R. V. 2020).
Mahasiswa juga membutuhkan motivasi dalam menjalani studinya sebagai kekuatan untuk mendorong semangat dalam menjalani perkuliahan dan untuk membantu menjaga kesehatan mental mahasiswa dengan memiliki motivasi baik motivasi yang dirinya sendiri atau dari orang lain. Memotivasi diri sendiri sangat penting dalam usaha menjaga kesehatan mental supaya kita tetap mampu bertahan dalam aktivitas yang kita jalani di tengah masa pandemi karena motivasi terkuat adalah motivasi yang berasal dari dalam diri kita sendiri dengan keinginan yang kuat sehingga kita mampu mendorong diri sendiri. Sebagai makhluk sosial, kita juga membutuhkan adanya peran orang lain salah satunya untuk memberi semangat dan motivasi yang positif (Rachmah, D. N., Mayangsari, M. D., \& Akbar, S. N. 2015).

Pelaksanaan dari pembelajaran jarak jauh sebenarnya juga memiliki sisi positif dengan manfaat yang dapat dirasakan bagi mahasiswa baru karena ditengah pandemi yang tidak memungkinkan untuk dapat belajar bertatap muka secara langsung di lingkungan kampus kita dapat tetap belajar serta menerima materi perkuliahan dari jarak jauh dengan memanfaatkan kemajuan teknologi, kita juga mendapatkan kemampuan untuk dapat menggunakan dan mempelajari teknologi di era digital saat ini. Melalui adanya manfaat ini mahasiswa perlu untuk lebih menumbuhkan rasa percaya diri dalam kemampuan bidang akademiknya, terlepas dari berbagai kendala yang dihadapi mahasiswa sedikit demi sedikit dapat merasakan esensi dari pelaksaan perkuliahan online di masa pandemi dan dapat 
menumbuhkan rasa percaya diri dengan kemampuan yang dimiliki, karena ketika mahasiswa merasakan rasa percaya diri yang besar maka semakin besar keinginan untuk melakukan yang terbaik dalam bidang akademiknya meskipun menghadapi berbagai kendala supaya dapat mengatasinya dengan baik sehingga kesehatan mental mahasiswa baru dalam menjalani perkuliahan di masa pandemi dapat tetap terjaga (C. P., Mayangsari, M. D., \& Rusli, R. 2020).

\section{KESIMPULAN}

Berdasarkan hasil penelitian dari sumber literatur yang digunakan sebagai metode penelitian tentang Kondisi Mental Mahasiswa Baru Menjalani Perkuliahan Online Pada Masa Pandemi menunjukkan bahwa kegiatan perkuliahan online yang dilaksanakan akibat pandemi mempengaruhi kesehatan mental mahasiswa baru karena dalam menjalani perkuliahan mahasiswa baru memiliki banyak kendala dan permasalahan sehingga menimbulkan rasa khawatir, menyebabkan stres, dan kesulitan memahami materi perkuliahan karena kendala jaringan yang sering terputus, sehingga mahasiswa baru membutuhkan motivasi, dukungan, dan kepercayaan diri supaya kesehatan mentalnya tetap terjaga dalam menjalani perkuliahan secara online di masa pandemi.

\section{DAFTAR PUSTAKA}

Abbas, E. W., \& Erlyani, N. (2020). Menulis di Kala Badai Covid-19.
Abbas, E. W. (2020). Menulis Artikel Jurnal. Menulis Artikel Jurnal.

Abbas, E. W. (2016). Mengatasi Kesulitan Menulis.

Aji, R. H. S. (2020). Dampak Covid-19 pada Pendidikan di Indonesia: Sekolah, Keterampilan, dan Proses Pembelajaran. Salam: Jurnal Sosial dan Budaya Syar-i.(7), 5, 395-402.

Amini, M., Mayangsari, M. D., \& Zwagery, R. V. (2020). Hubungan antara Kemandirian Belajar dengan Komitmen Tugas pada Mahasiswa Program Studi Psikologi. Jurnal Kognisia: Jurnal Mahasiswa Psikologi Online, 2(2), 149-152.

Fitriyani, Y., Fauzi, I., \& Sari, M. Z. (2020). Motivasi Belajar Mahasiswa Pada Pembelajaran Daring Selama Pandemik Covid-19. Jurnal Kependidikan: Jurnal Hasil Penelitian dan Kajian Kepustakaan di Bidang Pendidikan, Pengajaran dan Pembelajaran, 6(2), 165-175.

Hifzul Muiz, M., \& Sumarni, N. (2020). PENGARUH TEKNOLOGI PEMBELAJARAN KULIAH ONLINE DI ERA COVID-19 DAN DAMPAKNYA TERHADAP MENTAL MAHASISWA. EduTeach: Jurnal Edukasi dan Teknologi Pembelajaran, 1(2), 153-165. 
Putri, C. P., Mayangsari, M. D., \& Rusli, R. (2015). Menulis Membangun Mindset. (2020). PENGARUH STRES AKADEMIK TERHADAP ACADEMIC HELP SEEKING PADA MAHASISWA PSIKOLOGI UNLAM DENGAN INDEKS PRESTASI KUMULATIF RENDAH. Kognisia prodi Psikologi FK ULM, 1(2), 28-37.

Putri, L. A., Anward, H. H., \& Zwagery, R. V. (2020). PERBEDAAN KUALITAS PERSAHABATAN DITINJAU DARI GAYA KELEKATAN PADA MAHASISWA PSIKOLOGI FAKULTAS KEDOKTERAN ULM. Kognisia prodi Psikologi FK ULM, 1(1), 23-28.

Mayara, B. H., Yuniarrahmah, E., \& Mayangsari, M. D. (2017). Hubungan Kepercayaan Diri dengan Konformitas Pada Remaja. Jurnal Ecopsy, 3(2).

Rachmah, D. N. (2020). Cek Plagiasi: self efficacy, coping stres dan prestasi akademik mhs psikologi.

Rachmah, D. N., Mayangsari, M. D., \& Akbar, S. N. (2015). Motivasi belajar sebagai mediator hubungan kecerdasan adversitas dan prokrastinasi akademik pada mahasiswa yang aktif berorganisasi. Jurnal Cakrawala Pendidikan, 34(2). 